\title{
Monism and Meliorism
}

The Philosophical Origins of the Open Court

Nicholas L. Guardiano

\section{(2) OpenEdition Journals}

Electronic version

URL: http://journals.openedition.org/ejpap/1072

DOI: 10.4000/ejpap. 1072

ISSN: 2036-4091

Publisher

Associazione Pragma

\section{Electronic reference}

Nicholas L. Guardiano, « Monism and Meliorism », European Journal of Pragmatism and American Philosophy [Online], IX-2 | 2017, Online since 22 January 2018, connection on 19 April 2019. URL : http://journals.openedition.org/ejpap/1072 ; DOI : 10.4000/ejpap.1072

This text was automatically generated on 19 April 2019

\section{(c) $($ ) $\odot$ (8)}

Author retains copyright and grants the European Journal of Pragmatism and American Philosophy right of first publication with the work simultaneously licensed under a Creative Commons AttributionNonCommercial-NoDerivatives 4.0 International License. 


\title{
Monism and Meliorism
}

\author{
The Philosophical Origins of the Open Court
}

\author{
Nicholas L. Guardiano
}

\section{Monism as Raison d'Être}

1 The philosophic journal The Monist of the Open Court Publishing Company had not surprisingly its origin in monism, that is, in the philosophy of monism. From the inception of the journal in 1890 by its proprietor Edward C. Hegeler - a wealthy zinc industrialist - this worldview emphasizing unity or oneness in the world governed the journal's contents and editorial practices. Perhaps more surprising, however, is that monism played a major role in the founding and general mission of the Open Court company over all. The establishment of the publishing company was catalyzed by Hegeler's motive to promote his personal philosophic, religious, and moral ideas, which he believed the philosophy of monism summed up. As he bluntly stated in a letter to his first editor Benjamin F. Underwood, written in 1887 during the planning phases of the company: "To me it is an earnest effort to give to the world a philosophy in harmony with all facts (a monistic philosophy) which will gradually become a new religion to it, as it has to me."

2 Hegeler's agenda in the founding of his publishing company also involved the goal of promoting a "religion of science" or of "conciliating religion with science." The latter phrase would become the subtitle of the company's first publication, a biweekly magazine, named The Open Court. The program of "conciliation" involved - in this case by definition and by intent - having a group of thinkers come to an agreement on a specific idea. Hegeler further explains his motive to Underwood:

What leads me in this undertaking is not so much a sense of liberality, as a desire to communicate my ideas to others, to see them further developed, and also to have them contested. I feel they will be strengthened by contest, and look forward to it with pleasure [...]. The character of the journal must be such as to win the confidence of these specialists, and no effort or money be spared to secure their cooperation. ${ }^{2}$ 
The conciliation sought by Hegeler was the agreement of multiple persons on a single idea, and that idea was monism. His strategic plan was to recruit a mix of specialists in science, religion, philosophy, and other disciplines in order to set them on the common task of developing the doctrine of monism. And given that doctrine was of a religious nature to him, he proposed that "the first case before the [open] court is to be the 'Monistic Idea' vs. the 'Agnostic Idea'."

3 Although this early history of the founding of the Open Court is unambiguous about its mission, that mission began with only little support from its editorial staff. Prior to the publication of The Monist as its flagship journal in 1890, Hegeler had recommended its title as the name of his company's first publication. Writing to Underwood in December 1886, two months before the release of their first issue, he says:

I learn that the time has come when we have to publish the name and the programme of the new magazine we are about to found, and I here give you the conclusions I have come to: I adhere to the name, "The Monist," as that conveys most truly the leading idea I have in regard to this undertaking. ${ }^{4}$

The suggestion met with resistance by Underwood and his associate editor and wife Sara Underwood. The two were outspoken liberal writers involved with the freethought movement in the northeastern United States. Mr. Underwood - at the time completing his sixth year as editor of the leftist weekly The Index run by Boston's Free Religious Association - promoted a secularism and agnosticism (borderline atheism) while engaging in frequent public debates with clergymen. Meanwhile, Mrs. Underwood was a prominent feminist and woman's suffragist. ${ }^{5}$ Given their strong intellectual commitments, the Underwoods had serious reservations about the appropriateness of Hegeler's new title for reflecting the mission of the journal. The name they offered instead was the one that would stick, "The Open Court," which Sara originally thought up. It conveyed to the married couple a truly liberal agenda that was non-partisan and welcomed all points of view. Mr. Underwood explained his reasoning to Hegeler:

[L]et us not narrow [the journal] at the outset by giving it a name which stands for only a school or class of thinkers [monism or monist] [...]. Let the name be comprehensive enough to include in its scope the consideration of every school and system of philosophy. ${ }^{6}$

Hegeler attempted to compromise by proposing in return "The Monist's Open Court," yet, since this title still made monism central, it also was not well received.

After a series of letters, Hegeler would eventually concede to the Underwoods regarding the title of the magazine, although without conceding his mission. He directed the Underwoods to include in the forthcoming pages of The Open Court a standing notice maintaining an explicit statement about its monistic religious mission. Its first paragraph would read:

The leading object of THE OPEN COURT is to continue the work of The Index, that is, to establish religion on the basis of Science and in connection therewith it will present the Monistic philosophy. The founder of this journal believes this will furnish to others what it has to him, a religion which embraces all that is true and good in the religion that was taught in childhood to them and him. ${ }^{7}$

This statement or a version of it appeared in the journal throughout its early history, and thus Hegeler's ideological intentions were publically made known from the beginning of his publishing career. Meanwhile, the remaining of the standing notice attempts to incorporate some of the views of the editors, that is, the Underwoods. It proposes to synthesize monism and agnosticism, and to substitute "for blind faith rational religious views, for unreasoning bigotry a liberal spirit, for sectarianism a broad and generous 
humanitarianism." All the while, the "Contributors are expected to express freely their own views, [and] the Editors are responsible only for editorial matter."

5 Hegeler did not remain alone for long in the pursuit of his monistic agenda. When he was attempting to establish his publishing company in La Salle, Illinois from 1886-7, he sought a partner who agreed on the main doctrines of monism and would further them as the raison d'etre of the company. That is, while he needed a competent editor for his business enterprise, he moreover needed an intellectual ally for his cause. Here the Underwoods fell short. They were experienced and capable editors, but not advocates for monism, especially not if it involved establishing any kind of religion. Soon enough, Hegeler came to see them as dangerous agnostics possessing a liberal viewpoint antithetical to his monism. ${ }^{9}$ The disconnect resulted in them resigning their positions after less than one year, and Hegeler immediately filling the editorship enthusiastically with the German philosopher and fellow German-American immigrant Paul Carus.

Hegeler found an ideal intellectual partner in Carus: someone whose philosophical proclivities seemed commensurate with his own ideological inclinations. Prior to meeting Carus - who was residing in New York at the time - his excitement was peeked upon reading Carus's philosophical treatise Monism and Meliorism: A Philosophical Essay on Causality and Ethics (1885) and soon thereafter the short collection of poems Ein Leben in Leidern: Gedichte eines Heimathlosen (A Life in Song: Poems of a Homeless Person, 1886). These writings so captured Hegeler's attention that they compelled him to invite Carus to La Salle in order to help with The Open Court, as well as with the education of his children. Hegeler's first contact with Carus was by a letter written on 21 January 1887, only days before the opening release of the magazine. Its message would change their lives and the future of the publishing company.

Dear Sir - By the kind sending of your poems through our mutual friend, Mr. Underwood, you have given me much pleasure. The poems have brought you much nearer to me. After I had already known you through your treatise "Monism and Meliorism," to receive poems from you was quite unexpected by me.

I should like much to have you nearer La Salle, in order to have your help and advice in the work on the new journal, and I have been thinking if not a suitable position could be found for you in this vicinity. I must also mention that recently Mr. Salter spoke of you as qualified to bring my religious-philosophical ideas into shape for publication.

I do not know how you are situated at present; philosophical occupation alone would probably not fill your time satisfactorily; perhaps you would take charge of the education of older children. If so, there would be an opportunity for this here [...].

Again, many thanks for your poems, also for your treatise "Monism and Meliorism" which struck me very sympathetically, though I as a realist am but little acquainted with philosophic terms. I shall be glad to hear from you soon. ${ }^{10}$

Carus had given expression to the philosophy of monism that Hegeler - a practicallyminded, "realist" entrepreneur and engineer - had deeply felt but could not sufficiently articulate. In finding Carus, Hegeler found a voice in a professionally trained philosopher. Hence, Hegeler made the impetuous decision to ask a man, whom he had never before met, to move across the country and take a leading role in his personal business and family life - all in the name of monism.

On the other hand, Carus found an intellectual ally and willing benefactor in Hegeler. Carus had been forced to resign from his first career as an instructor in his homeland Germany in 1881 upon falling out of favor with school authorities due to his unorthodox 
religious views. He then became an "exile" (exile) and "homeless person" (heimathlosen) in his words - emigrating to Belgium, England, and then to the eastern United States, with his activities consisting in a mix of teaching, lecturing, and editing. Thus, after a trying six-year period without consistent employment or residence, Carus finally found a welcomed home in La Salle with the Hegeler family. ${ }^{11}$ This would provide a permanent place to settle down and an environment for the development of his ideas.

Carus accepted Hegeler's invitation, relocated from New York to Illinois, and began work in his new capacities with the Open Court and Hegeler family. He was in La Salle by March 1887, in time to help with the first volume of The Open Court. He contributed an article to the second issue of the magazine of March 3rd and contributed other articles to seven of the remaining twenty publications that year. In addition to his contributions as an author, he was immediately assisting with editorial matters. Thus, by December when the Underwoods decided to resign, Carus was literally waiting in the wings of the editorial office. Moreover, Carus had made a very personal and intimate connection with the Hegeler family during his first year in La Salle. He had become romantically involved with Mr. Hegeler's daughter, Mary Hegeler, and asked her hand in marriage..$^{12}$ Come March the following year, the two were husband and wife, and Carus was now Mr. Hegeler's son-inlaw.

9 The new position as editor-in-chief and his relationship as a new family member would sufficiently solidify his partnership with Hegeler. They set out during the coming years to work together to ground the Open Court on the principle of monism. The revised standing notice of The Open Court appearing in the first issue under Carus's editorship succinctly expresses the intellectual terms of the partnership: "The Journal is devoted to the work of conciliating Religion with Science. The founder and editor have found this conciliation in Monism, to present and defend which will be the main object of THE OPEN COURT." ${ }^{13}$ These two sentences make a direct and unapologetic statement in comparison to the multi-paragraph original standing notice, which winds together tenuously the ideas of religion, science, monism, agnosticism, liberalism, and humanism. With the Underwoods out of the picture, Hegeler need no longer compromise and could move forward unimpeded with his decided agenda for his publishing company.

\section{The Open Court Philosophy}

10 Monism was the ideological or philosophical ground of the Open Court Publishing Company; it served as the catalyst bringing together Hegeler and Carus as colleagues in a joint effort. But, why monism, that is, what was significant about this philosophy over others? Moreover, to what specific kind of monism did Hegeler and Carus mutually subscribe?

11 Carus's book Monism and Meliorism is an ideal source for arriving at an understanding of the monism of the Open Court. His biographer Harold Henderson says that the book "is the best evidence we have of the thoughts that Paul Carus brought to La Salle and that appealed to Edward C. Hegeler." ${ }^{14}$ Hegeler found his own intellectual sentiments expressed in the text and for this reason became convinced that Carus possessed the qualifications to give proper shape to his personal worldview.

The book was Carus's first in English, written during his early years as a philosopher. Carus's philosophical career may be summed up as representing two (not necessarily 
mutually exclusive) theoretical poles: monism and the philosophy of form. ${ }^{15}$ With Monism and Meliorism published in 1885 and The Philosophy of Form published in 1911, these texts amount to culminating expressions in the evolution of his philosophy. From the time of receiving his doctorate from the University of Tübingen (1876) through his early tenure with the Open Court in the United States, the monistic philosophy was at the core of his thinking. In addition to the book Monism and Meliorism, we see Carus's preoccupation with a monistic worldview across many writings: Metaphysik in Wissenshaft, Ethik und Religion: Eine Philosophische Untersuchung (1881), Ursache, Grund und Zweck: Eine Philosophische Untersuchung zur Klärung der Begriffe (1883), Principles of Art, from the Standpoint of Monism and Meliorism (1886), "Monism, Dualism, and Agnosticism" (1887), "Monism and Religion" (1888)," "The Oneness of Man and Nature" (1888), "The Religious Character of Monism: In Reply to the Criticism of Dr. Gustav Carus" (1888), "The Foundation of Monism" in Fundamental Problems: The Method of Philosophy as a Systematic Arrangement of Knowledge (1889), Monism its Scope and Import: A Review of the Work of the Monist (1891-2), "Monism Not Mechanism: Comments upon Prof. Ernst Haeckel's Position" (1892), and "Professor Haeckel's Monism" (1892). As early as Metaphysik in Wissenshaft, Ethik und Religion composed soon after receiving his doctorate and while still in Germany - Carus argues for the preeminent place of monism over other systems of metaphysics. ${ }^{16}$ Likewise, in Ursache, Grund und Zweck, he boldly states that monism is no less than "den wichtigsten Grundpfeiler einer philosophisch-wissenschaftlichen Weltanschauung" "the most important cornerstone of a philosophical-scientific worldview"). ${ }^{17}$

Another notable text for our purposes, among the many listed here, is the article "Monism, Dualism, and Agnosticism." It appeared in The Open Court only two months after Carus arrived in La Salle and is his first presentation of monism within the pages of the journal. Moreover, it was written under Hegeler's close guidance. Hegeler had helped prepare the article by proof reading and editing drafts prior to Carus submitting it to Underwood for publication. ${ }^{18}$ In this way it was the first philosophical collaboration between Carus and Hegeler and was Carus's first attempt at using his expertise in order to give voice to Hegeler's beliefs.

Throughout his writings on monism, Carus provides explicit definitions of the philosophy and frequently returns over the course of his discussions to its most fundamental tenets. One definition appears on the opening page of the preface to Monism and Meliorism. It states: "We define Monism as a conception of the world which traces all things back to one source, thus explaining all problems from one principle." 19 This simple statement is almost tautological since it does not describe a unique kind of monism. Rather, it indicates the general position common to all forms of monism, which is the grounding of a multiplicity in some kind of unity. The definition also does not inform us about the nature of the presumed monistic source, principle, or what have you. However, later in the book, Carus fleshes out his view by arguing that the universal principle governing the world is causality. By the law of causality Carus in effect distinguishes his position from other versions of monism. This is one of two of his major theses. The other is meliorism, which is an ethical position theoretically interconnected with monism. Together the two doctrines comprise the systematic plan of the text: "Causality is the beginning, ethics the aim and end of this philosophy. These two points being fixed, the whole system is sketched in its outlines." ${ }^{20}$ I will address each of these theories in turn. However, first it is necessary to discuss the introductory chapter, where Carus presents the historical 
background he believes serves as foundation or "pedestal" for his systematic philosophy. 21

Monism and Meliorism begins by putting forth a quintessential philosophical problem: the problem of dualism. An examination of Carus's criticism of dualism allows for a proper understanding of his more positive doctrines, since he proposes these as necessary solutions. Dualism commits itself to two distinct fundamental principles or forms of reality. A classic historical example is Cartesian dualism that proposes that the human being consists in mind and body and that the world as a whole is populated by the two substances of mind and matter. These substances are incommensurate because the former is a thinking, non-extended being and the latter is an extended, non-thinking being. Carus will reject this dualism (among others) because it does not account for the interaction between the two entities given that they are ontologically distinct. However, in his book, he primarily focuses his critical efforts on the dualistic tendencies not of Descartes, but of those that he believes are present in Kant's philosophical system. Some of the dualisms that Carus identifies here consist in the following pairs: subject/object, reason/feeling, scientific inquiry/religious faith, a priori knowledge/a posteriori knowledge, optimism/pessimism, ideal/real, necessity/freedom, natural law/moral obligation. A major goal for Carus is to expunge these dualistic flaws from Kant's revolutionary philosophy, so to advance a progressive reconstruction of it in a philosophy of monism.

16 Carus's motives here have an important historical context in the philosophical currents of the second half of the German nineteenth-century. His student years and subsequent teaching career in the 1870s and 1880s overlapped with the rise of neo-Kantianism in Germany. During his residence at the universities of Greifswald, Strasbourg, and Tübingen, as a student, and then subsequently in gymnasia and the military academy in Dresden, as a teacher, academicians of the likes of Kuno Fischer (1824-1907), Friedrich Lange (1828-75), and Otto Liebmann (1840-1912) had been actively laying the foundations for a new approach to Kant. ${ }^{22}$ They and their peers were motivated by a strong reaction against two major ideological trends that had become popular following Kant: on the one hand, the speculative idealism of such thinkers as Fichte, Hegel, and Schelling, and, on the other hand, the dogmatic scientific materialism of such figures as Karl Vogt (1817-95), Heinrich Czolbe (1819-73), and Ludwig Büchner (1824-99). In light of the perceived failings of these developments since Kant, Fisher and Liebmann advocated for a return to the writings of the Sage of Königsberg and a reassessment of their actual doctrines and critical methods. As a sign of the times, Liebmann in his book Kant und die Epigonen (1865) ended each chapter with the emphatic refrain: "Thus we must go back to Kant." Following upon such impulse, by the 1890s two schools of neo-Kantianism would emerge, each advocating their own way of returning to Kant: the Marburg School with its predecessor Lange and main representatives Hermann Cohen (1842-1918) and Paul Natorp (1854-1924); and the Southwest or Baden School with its predecessors Fischer and Hermann Lotze (1816-81) and main representatives Wilhelm Windelband (1848-1915) and Heinrich Rickert (1863-1936). From a historiographical perspective, albeit a generalization, the two schools can be seen in opposition whereby the former attempted to clarify Kant's views and adhere to his methodical practices, and the latter attempted to explore the wider implications of Kant's ideas to contemporary culture. ${ }^{23}$

Carus left his native homeland in 1881, before the establishment of any distinct school of neo-Kantianism, which would continue into the first two decades of the twentieth 
century. For this reason alone, he is not a card-carrying "neo-Kantian." Furthermore, despite Carus's time in Germany overlapping with the rise of the movement, his early writings make almost no explicit reference to its figures, texts, or internal academic debates, which were numerous and created fierce forms of partisanship across the universities. Nevertheless, when assessing Carus's relationship to neo-Kantianism and its origins, we should keep in mind Klaus Köhnke's observation that, viewed from within, the rising movement was hardly perceptible and consisted in heterogeneous currents flowing together of which "not one of the active participants in this process understood itself as part of a more comprehensive movement." ${ }^{24}$ The bottom line is that Carus's first philosophical ideas were born out of the same intellectual, social, and political milieu that came to define the neo-Kantians, and, as we might expect, they share with the neoKantian program the effort to make recourse to Kant while critically assessing the philosophical trends post-Kant.

18 A general spirit of neo-Kantianism is evident in Monism and Meliorism that takes Kant's philosophy as its starting point. The first chapter is a review of Kant's critical project both its theoretical and practical sides - in historical perspective, as a response to the insights of Enlightenment philosophy. Carus there echoes one of Kant's most influential ideas by cautioning against the dangers of speculative reason and by showing a commitment to grounding scientific knowledge on a priori truths. The idea was a major point of emphasis with his German contemporaries who focused on epistemology as a systematic concern. Notably, Fischer in his influential writings on Kant sought to define the precise boundaries of reason using a critical idealism that attacked the materialistic presuppositions of natural science and attempted to reground scientific knowledge exclusively on the a priori forms of cognition. ${ }^{25}$ However, for Carus, even Fischer, "who is perhaps the most impartial interpreter" of Kant, does not recognize one of the fundamental principles of Kant's philosophy; this is its dualism. ${ }^{26}$ Carus explains that Fischer among other scholars overlook the combination of the "antagonistic principles" of "Materialism" and "Spiritualism" inherent in the Kantian system. These drive the contrary worldviews of the Critique of Pure Reason and Critique of Practical Reason, that is, the contrast between a thoroughly deterministic physical world, on the one hand, and a practical world of freedom that also admits God and the immortality of the soul, on the other hand. Prior to Kant, the history of these antagonistic principles lead to the opposition between British skepticism - stemming from Locke and Hume - and German dogmatism - stemming from Leibnitz and Wolf. And now in the post-Kantian era, they reappear, "though more moderately [...] in the Realism of modern science and the Idealism of transcendental philosophy." ${ }^{27}$

Putting aside the question of the accuracy or novelty of Carus's interpretations of Kant and of the history of philosophy, his views nonetheless inform his philosophy of monism. This is because he believes that Kant's dualism has precipitated a state of partisan scholasticism with conflicting and one-sided interpretations, thus setting the stage for a unifying voice. In order to overcome our disagreements and truly reap the benefits of Kant's insights, we must first acknowledge that his philosophy is truly dualistic and second strive to reconcile its opposing elements. Thuswise Carus explains that Kant successfully "incorporated the antagonistic principles of his time in his philosophy, [yet] he left the working out of the solution to posterity." ${ }^{28}$ That solution Carus envisions is the unification of the principles in a theory of monism. To achieve this is the aim of his book. On the other hand, the method of achieving the goal is Kant's own method, which is 
"actually a principle of justice."29 This method preserves each side of an issue and treats neither as inferior nor superior to the others. Hence, Carus concludes his first chapter with the following plan of action:

The following articles try to realize this ideal, and will prove, let us hope, that there is more unity in the general plan of human reason than Kant supposed. Our monism results in a contemplation of the world by which so many seemingly contradictory truths are reconciled with each other: the ideal on the one side, with the real on the other, logical deduction with empirical induction, religious faith with philosophic and scientific inquiry, the inflexible causality with a higher teleology, and the rigid law of necessity with freedom of will and morality. ${ }^{30}$

The specific dualism of religion and science that Carus names in his monistic reconstruction of Kant's philosophy is especially relevant to his future role as editor of The Open Court. "Conciliating religion with science" was the stated aim of the magazine, appearing in the subtitle and standing notice, and it was part of Hegeler's mission in founding the publishing company. Carus's attention to this problem must have appealed to Hegeler when reading Monism and Meliorism. As future business partners, the two men will both insist on the imperative to reconcile this dualism, along with the parallel dualism of feeling and reason. As Carus puts it in his book, the reconciliation is necessary in order to avoid falling into an extremism of either "radicalism" or "dogmatism," each prioritizing one aspect of the dualistic pair over its counterpart. Radicalism, for Carus, is the atheistic view rejecting religious faith in an over commitment to reason. On the other hand, dogmatism is the superstitious view rejecting scientific truths in an over commitment to feeling. These alternative positions are furthermore expressions of the greater historical antagonisms of Materialism/Spiritualism and Realism/Idealism, opposing worldviews brought into full relief by Kant's varying approaches in his Critiques. In accordance with the "method of justice," Carus takes neither of these views to be satisfactory alone, and instead seeks a balanced position in establishing a scientificreligious philosophy that holds a comprehensive view of human nature.

Carus's solution to dualism that equally incorporates two fundamental principles may be deemed "neutralism," recalling Charles Peirce's description of neutralism as a kind of faux monism. From at least 1890 onward, Peirce was attentive to the happenings of the Open Court and the philosophical efforts made by Carus; he found he shared similar ideas with Carus, yet also had critical objections to others. In his 1891 article "The Architecture of Theories" for The Monist, Peirce describes neutralism as that brand of monism that holds physical law and psychical law to be both independent and primordial. Furthermore, he rejects the theory stating: "Neutralism is sufficiently condemned by the logical maxim known as Ockham's razor, i.e., that not more independent elements are to be supposed than necessary. By placing the inward and outward aspects of substance on a par, it seems to render both primordial." ${ }^{31}$ Peirce's own metaphysics, rather, is a monism of "objective idealism." Unlike neutralism and materialism (the third version of monism), objective idealism is the "one intelligible theory of the universe"; it holds psychical law to be primordial to physical law and "matter is effete mind." ${ }^{32}$ Although Peirce does not name Carus or anyone in particular as a neutralist, his remark in "The Architecture of Theories" has a not minimal probability of having him in mind amongst others, since the two were by then corresponding on philosophical issues. In addition, Peirce's explicit comment on Carus's monism in his review of the first issue of The Monist published in The Nation shows that he finds Carus's position to share a point of confusion similar to the doctrine of neutralism. There he claims that Carus's definition of monism is "no 
definition of monism at all" and that it inappropriately opposes itself to idealism and materialism, whose meanings Carus misunderstands. ${ }^{33}$

There is more to Carus's monism that "traces all things back to one source" than a mere diplomatic perspective that adjudicates a middle ground between theoretical extremes. For him, there is a monistic source of all things, that is, there is an ontological principle of unity. The article "Monism, Dualism, and Agnosticism" makes this clear: monism is the "conception of the world which traces being and thinking, the object and the subject, matter and force back to one source, thus explaining all problems from one principle." ${ }^{34}$ What is this one "source" or "principle"? Carus's answer is causality, which he submits as a positive solution to the reductive extremes that stem from dualistic thinking. "Causality is the keystone of all philosophic difficulty, and all other problems depend upon the solution of this query [...]. There is no problem in the empire of the human mind, which is not more or less connected with causality." ${ }^{35}$ Also, the nature of causality is foremost an objective and universal law strictly governing all events necessarily. It governs not only physical interactions but also mental processes. In addition to this ontological role, Carus understands causality to play an epistemological role. Causality in this sense is the basis on which we reason in our efforts to discover truths about the world. This is because knowledge, in the physical sciences, psychological sciences, and other disciplines, consists in identifying causal relationships.

These two senses of causality appear in Carus's synopsis of the three essential doctrines of monism. The so-called "trinity of monism" states:

Monism means, 1. a unity of source to which it traces the origin and explanation of all things and phenomena both spiritual and material, 2. a unity of principle animating the whole world, arranging the order of motion or the mechanics of causality, and 3. a unity of its finis [end]. There is everywhere the same goal, whither the development of evolution tends. ${ }^{36}$

This trinity covers the scope of monism as a systematic enterprise, referring to its method, metaphysics, and ethics, respectively. ${ }^{37}$ The first aspect I have already discussed, and the third aspect I will address below in terms of the doctrine of meliorism. At any rate, all three aspects make evident that a causal monism is Carus's answer to the problem of dualism. The unities of "source," "principle," and "finis" each indicate a unity of causality. For instance, the unity of the principle of causality has a universal presence in the world and thus unites under one natural law the diversity of beings both physical and psychical. In this way Carus imagines his monistic thesis to achieve a fully comprehensive theory of the universe.

Carus's pronouncements on a causal monism in Monism and Meliorism follow up his claims made in Metaphysik in Wissenshaft, Ethik und Religion on the deeper metaphysical nature of causality. In section 14, "Das Metaphysische," he assumes the traditional Kantian distinction between two worlds: "the metaphysical" world as an unknowable thing-initself and the phenomenal world of physical objects in space and time. He notes that the thing-in-itself has been variously interpreted in the history of philosophy as Spinoza's causa sui, Hegel's Absolute, and the mystic's God. Although Carus tells us that it is the height of human arrogance to speculate about it - like the "flight of Icarus" - he does not altogether dismiss the thing-in-itself as a nonsensical idea. Rather, he maintains its reality and states it is "das 'An sich' und der letzte Grund der Dinge" ("the 'In-itself' and the ultimate Ground of Things"). ${ }^{38} \mathrm{He}$ adds that the metaphysical world "becomes the physical" world, and as "the common Root" of the forms of space, time, and the laws of nature, it is "Necessity" or "Causality." ${ }^{39}$ These speculative metaphysical remarks about 
causality go well beyond a statement of its mere epistemological role in structuring experience and grounding knowledge. In the Kantian-inspired treatise on metaphysics, causality is associated with - whether successfully or unsuccessfully - the necessary relationships between phenomenal events in space and time, as well as with the primordial relationship between the phenomenal and metaphysical worlds, whereby the latter is the ultimate source of the former.

Carus's deterministic worldview was no passing thought. While Metaphysik shows his interest in causal determinism prior to writing Monism and Meliorisim, his publications in the 1890 s and beyond continue to do the same. For instance, he emphatically returns to it in several articles published in The Monist from 1892-3. In these articles he passionately defends his position against challenges made by Peirce. Peirce's own view is that an element of absolute chance or spontaneity with no degree of conformity to law is inherent in the world - a doctrine he calls "tychism" from the Greek word for "chance." He supports this position in his Monist article "The Doctrine of Necessity Examined" (April 1892), which presents a series of arguments intended to refute "necessitarianism" (Peirce's term for determinism). Despite Peirce's cogent arguments that show necessitarianism to be untenable, Carus was stalwart in his position. As a result, the two philosophers began to debate the issue back and forth in a series of letters and Monist articles. Initially, Carus countered Peirce by publishing "Mr. Charles S. Peirce's Onslaught on the Doctrine of Necessity" (July 1892), and then three months later publishing "The Idea of Necessity: Its Basis and Its Scope" (October 1892). The following year, Peirce would respond with "Reply to the Necessitarians: Rejoinder to Dr. Carus" (July 1893) and Carus immediately again with "The Founder of Tychism, His Methods, Philosophy, and Criticisms: In Reply to Mr. Charles S. Peirce" (July 1893), both published in the same issue of The Monist.

The debate covering five articles and a total of 165 printed pages is too complex to fully consider here - it duly deserves a complete study unto itself $\mathrm{f}^{40}$ - yet a quality of Carus's defensive posturing is noteworthy. While distinguishing his philosophy from Peirce's, he expresses the strength of his commitment to a traditional Kantian view of causality. In "Onslaught" he entrenches himself in a kind of Kantian a priori argument in order to justify his necessitarianism.

The doctrine of necessity, let us not be afraid to pronounce it clearly, is of an a priori nature. The scientist assumes a priori, i. e. even before he makes his observations or experiments, as a general law applicable to every process which takes place, that, whatever happens, happens of necessity in consequence of a cause and in conformity to law, so that the same cause under the same circumstances will produce the same effects. ${ }^{41}$

All natural laws, including the law of causality, Carus claims are known a priori, not as a "natural belief" or "innate idea," but as "simply and solely formal knowledge, such as $2 \times 2=4$, to which we attribute universality and necessity." ${ }^{\prime 2}$ As a consequence of the a priori character of natural laws, they furthermore are "eternal," unchanging forms of the knowing subject, or facts of nature known "sub specie aeternitatis." ${ }^{43}$ On these grounds, Carus also contradistinguishes his position from Peirce's view of natural laws as products of evolutionary growth existing as regularities or "habits" of the universe.

In an effort to thoroughly cover his basis against Peirce, Carus also adds that his a priori method of fixing the truth of necessitarianism is not equivalent to the "a priori method" of inquiry Peirce features in "The Fixation of Belief" (1877). There Peirce shows that the "a priori method" is unscientific because it determines conclusions in accordance with 
one's subjective inclinations, rather than in accordance with a community of like-minded inquirers. Carus concurs that such a method would not settle upon a set of consistent and reliable beliefs, given the multitude of individuals with their varying interests. Hence, he accordingly chastises it for bringing about the death of science, philosophy, morality, and, worst of all, for leading to the dreadful position of agnosticism. ${ }^{44}$ Ironically and despite his passionate tone here, Carus's response appears not to recognize that the validity of his own a priori method remains under the burden of proving itself other than subjective. The question remains: What evidence is there for a deterministic universe beyond Carus's own personal inclinations for the truth of his causal monism? Or, in terms of his Kantian presuppositions: What proof is there that we possess an indubitable formal knowledge of the absolute law of causality?

Carus remained a committed determinist to the end of his life. As the decades passed, he never ceased his contention with Peirce's tychism. In a letter to Peirce written in 1913, when Carus was 61 years of age, he expresses his interest to republish their Monist debate as a standalone volume. ${ }^{45}$ Also, in his final systematic work The Philosophy of Form, he continues to present a Newtonian conception of an objective world order that is strictly governed by universal and eternal laws. Consequently he would hastily dismiss as incredulous Einstein's revision of Newtonian mechanics and theory of special relativity with its relativistic views of space, time, and matter. ${ }^{46}$

The third important way in which Carus understands causality, beyond its ontological and epistemological modes, constitutes the third part of his "trinity of monism." It conceives causality as a force guiding the ends toward which phenomena are directed. That is, it is a theory of final causality, and Carus applies it to ethics. The concept of final causality historically traces back to Aristotle, who spoke of final causes in nature when, for instance, referring to the natural places toward which the elements move. Kant also employed the idea when describing the intentionality of human action and the "purposiveness" of natural organisms. Following Kant, the German idealist G. W. F. Hegel used final causality in his account of human history as teleological. These philosophers and others who believe in the reality of final causality make up the historical background to Carus's appropriation of it to his ethics of meliorism.

The final chapter of Monism and Meliorism covers this last leg that completes the system of monism. Just as Carus seeks to overcome the dualisms between Materialism/Spiritualism and Realism/Idealism, he seeks to overcome any split between philosophies that limit themselves to admitting the reality of only one of the two opposing types of causality, namely causa efficientes and causa finales. The theoretical move once again follows the neutralistic program of promoting a balanced perspective, in this case by comprehensively admitting the reality of both types of causes.

Carus's position here will ground his ethical claims, and he makes it palpably clear while distinguishing his brand of monism from the monism of Ernst Haeckel. Haeckel's naturalism rejects the existence of all spiritual entities and supernatural powers; it affirms all that exists are nature and mind, the physical and psychical, and these are united under one set of natural laws. Consequently, Haeckel considers the knowable world to form a single unitary whole for scientific inquiry. To this extent, Haeckel's monism is similar to Carus's. However, Carus diverges from Haeckel regarding Haeckel's "mechanicalism" or mechanism, which only admits the reality of efficient causality throughout the operations of the universe. Haeckel assumes that not only physical things but psychical things, as well - biological organisms, life, feelings, and ideas - are 
reducible to mechanistic processes exclusively governed by efficient causes. Haeckel's naturalism thus fits the profile of "materialism," as defined by Peirce's list of three possible forms of monism: materialism takes "the psychical law as derived and special, the physical law alone as primordial." ${ }^{17}$ Carus's neutral monism, on the other hand, accepts the reality of both mechanical and purposive processes, efficient and final causes. For him, the two types of causes coexist in the universe and are compatible by each having their own domain of application: efficient causality applying to the mechanistic world of physical bodies, and final causality applying to the psychical world of ideas and feelings. The latter, for Carus, are subjective states of consciousness and not merely motions of the physical brain, as Haeckel claims. ${ }^{48}$

Given this systematic background of Carus's theory of causality, we can best understand the specific doctrines of his ethics. Meliorism holds a unity of final cause shared by all. That is, the world populated by all its diverse beings moving in all their diverse ways naturally possesses "a unity of its finis [end]. There is everywhere the same goal, whither the development of evolution tends." Moreover, this final end will be "the amelioration of the present state," that is, a future state that is superior to past states. ${ }^{49}$ The presence of such a melioristic or progressive trend in the universe is most evident in the historical growth of human civilization. This historicist idea was not uncommon in the nineteenth century, and Carus and Hegeler converged on it in their separate ways. Hegeler also presents the view in his lecture "The Basis of Ethics," which was delivered before the Society for Ethical Culture in Chicago and later published as an article in the first issue of The Open Court. He states that the "greatest good" is to "[p]reserve and evolve the human form of life," and scientifically defends the thesis on the basis of the physiological structure of the brain. ${ }^{50}$ As colleagues working together to establish an Open Court philosophy, both men thus jointly envisioned a natural course of history in which the overall condition of civilization and the human form is steadily improving.

Furthermore, the two thinkers concur that the final amelioration is not in the form of an increase in personal happiness but in the form of an increase in the general moral state of humanity. Carus says:

We do not live to be happy. Our inmost nature compels us to perform some tasks in the service of some thing higher than our personal existence, be it in the field of science or art, be it by inventions or by extending trade and commerce or by the propagation and education of posterity; in one word, be it by any progress or improvement, we are compelled to do some thing in the service of humanity. ${ }^{51}$

Hence, the ethics promulgated by the Open Court does not advocate individuals seek personal pleasure or engage in creative pursuits for themselves. Rather, it advocates individuals serve the greater good of humanity in the long run, whether or not their efforts happen to benefit their present lives.

The ethics of meliorism reveals another dimension of Carus's reconstruction of Kant's philosophy and dualistic tendencies. There is a unity of principle to the ethical life by moral progress existing simultaneously as a natural law and practical imperative. Whereas Kant draws a divide between the phenomenal and noumenal realms on the basis of his dichotomous concepts of nature and morality, Carus aims to unite these dualisms. That is, whereas the Kantian philosophy claims that nature is exclusively governed by necessary laws and that morality is exclusively governed by freedom of will, the monistic philosophy strives to unify the (seeming) disparity. As Carus puts it: monism is the theory of the unity of the "must" and "ought." The "must" corresponds to the necessary path that history must follow toward its ameliorative end. It is fixed by an unbreakable law, rather 
than open to the arbitrary decisions of human beings. The "ought," on the other hand, corresponds to the ethical demand ordaining that human beings should strive to bring about that higher end of history regardless of the immediate consequences. Thus, the right thing to do is to work diligently to achieve the moral progress of humanity, whereas it is wrong to pursue one's personal benefit or to live a life of moral indifference.

For a life worthy to be lived is one that is full of active aspiration, for something higher and better; and such a contemplation of the world we call meliorism. Let the world be bad! our duty is to work with steady labor for its improvement. ${ }^{52}$ that one consequence of such a monistic ethics is that it is against "individualism": the belief that the "individual soul is an ultimate unit," a "little God." ${ }^{33}$ Rather than monads in possession of their own substantial nature,

single individuals are transient things which consist of the ideas they think and the ideals they aspire for [...]. It is not the individual who is an independent existence, but humanity which lives in the individual; and the great ALL lives in humanity. The individual is only one insignificant and transient state of the great development of human kind, it is one little link in the unmeasurable chain of life. ${ }^{54}$

From the perspective of meliorism, the individual is subordinate to the greater development of humankind; it is merely a means for the universal growth of humanity. Historical precedence for this idea is found in Hegel's teleological view of history. For Hegel history is the concrete embodiment of the development of geist, which strictly follows a rational plan toward a fixed end. The specific individuals appearing in history are inconsequential to the deterministic process that advances along discrete stages and types of Western society. While Hegel admits the existence of a few special "Worldhistorical individuals" who are representatives of geist at a particular stage, even they are ultimately reducible to the societal norms and greater spiritual forces of world history.

As with the monism of the Open Court, the meliorism of the Open Court was not a unique innovation in the history of philosophy. In addition to its theoretical affinities with Hegel's philosophy of spirit, it shares a family resemblance to an American strand of meliorism. Meliorism was a live idea in the United States in the nineteenth and subsequent twentieth centuries, as witnessed in the writings of Ralph Waldo Emerson, George Ripley, Margaret Fuller, the abolitionists, Peirce, William James, John Dewey, Charlotte Perkins Gilman, Jane Addams, W. E. B. du Bois, Martin Luther King Jr., Richard Rorty, Cornel West, and numerous other philosophers and progressive thinkers. A wellknown formulation of the doctrine appears in James's Pragmatism and affirms the power of human action to affect positive change in an inherently imperfect world. Specifically, for James, meliorism consists in an attitude midway between the extremes of optimism and pessimism, between a "tender-minded" and a "tough-minded" disposition. Whereas the former believes the salvation of the world is inevitable and the latter believes the salvation of the world is impossible, the meliorist believes in the possibility of improving the conditions of life from a cautiously optimistic point of view..$^{55}$ The family resemblance between James's meliorism centered on human psychology and Carus's meliorism centered on a cosmological principle of final causality only goes so far. James's antifatalistic presupposition and focus on the power of the individual psyche contrasts with Carus's historical determinism, anti-individualism, and general Kantian framework of a deontological ethics based on duty. A limited resemblance is also the case with the actionoriented pragmatists after James. While challenging traditional conceptions of domestic life, labor relations, race, gender roles, and other societal norms, they sought to reform 
problematic living conditions for the betterment of society. As with James, they promoted self-control in the shaping of one's personal destiny, rather than abeyance to a foreordained historical fate.

Beyond these psychological and social-political forms of meliorism, a metaphysical form appears in Peirce's philosophy. While exchanging ideas with Carus over his 1890 Monist articles, Peirce was formulating an evolutionary cosmology of his own on the basis of his tychism. Peirce hypothesizes at the end of "The Architecture of Theories" that the universe as a whole is growing from a state of pure indeterminacy to a state of determinacy, "a chaos of unpersonalized feeling" sporting in arbitrariness to an absolute reign of law and reason. ${ }^{56}$ Fueled by the spontaneous energy of tychism, the growth of the universe is "hyperbolic," that is, always in a state of incipiency with the potential to develop in novel ways. In addition, its growth is "variescent" by the generation of an endless variety of novel forms, which themselves flourish forth in the stimulation of more and more novel forms, ad infinitum. In this evolutionary universe, individuals may partake in the creative process by embodying its results in the discovery of new scientific ideas, expressions of works of art, innovations in technology, and the establishment of new ways of life. ${ }^{57}$

Once again Peirce proves a formidable interlocutor for Carus on the metaphysical underpinnings of his philosophy. In contrast to Peirce's hyperbolic universe, Carus's "parabolic" universe is strictly determined and a closed system, tending on the whole toward a single foreordained state. Explicitly calling out Carus by name, Peirce in the final article of his Monist series, "Evolutionary Love," critiques Carus's melioristic universe as a degenerate form of evolution..$^{58}$ For Peirce, there are three historical modes of evolution: (1) evolution by fortuitous variation (tychasm - Darwin), (2) evolution by mechanical necessity (anancasm - Hegel, Carus), and (3) evolution by creative love (agapasm - Henry James Sr., Peirce). The essential flaw of anancasm, such as found in Carus's meliorism, is that it does not admit a "living freedom" in its conception of reality as intrinsically good. It also lacks a guiding principle of love to advance its forward progress by self-less acts, instead operating on the basis of a principle that austerely deals out pre-established destinies. Peirce's agapism, on the contrary, makes central a cosmic principle of love that nurtures the seeds of living freedom and supports the formation of new evolutionary forms as unique autonomous creations. ${ }^{59}$

Meliorism provides the final leg of Carus's monism as he formulated it at the time of the founding of the Open Court. As we have seen, Hegeler agreed with and embraced Carus's philosophy, and this lead him to nominate Carus as his personal ambassador for establishing monism as the ideological foundation of his publishing company. However, prior to meeting Carus and discovering his philosophical writings, Hegeler had already arrived at an idea of monism through his own amateurish reflections and made independent attempts to explain it in writing. An examination of the writings by the owner of the Open Court further fleshes out the company's philosophical origins.

Hegeler expresses his view of monism in a few different places: his early planning letters to Underwood, the original standing notice of The Open Court, and two Open Court articles, "The Basis of Ethics" (1887) and "What the Monistic Religion is to Me" (1888). These writings make one thing clear: that a defining factor of Hegeler's interest in monism is his personal religious belief. He candidly tells Underwood in one of his planning letters:

The programme of the paper we should be perfectly clear about. To me it is an earnest effort to give to the world a philosophy in harmony with all facts (a 
monistic philosophy) which will gradually become a new religion to it, as it has to me. ${ }^{60}$

This religious intention Hegeler goes on to voice publically in the first standing notice of The Open Court. There he states that the mission of the journal is to recruit the principles of monism in order to "establish religion on the basis of Science." This original form of the mission statement contains a subtle difference from the one expressed in the revised standing notice, as well as in the journal's subtitle, appearing under Carus's editorship, that simply seeks "conciliating Religion with Science." The original suggests a goal that is more blatantly religious than the revision that suggests a goal that is more neutral or impartial toward religion and science.

While corresponding with Underwood, Hegeler also takes a stab at articulating a metaphysical theology that would ground his "new religion" while interpreting a passage from the Christian Bible. He explains that the

name, "The Monist," conveys the idea given in the New Testament in the passage, "For in Him we live and move and have our being," when the meaning of the word Him or God, which is that of a person or individual, that is a limited being is enlarged in accord with our present knowledge to that of the continuous "All," which includes everything, also ourselves. ${ }^{61}$

Hegeler's interpretation suggests a kind of pantheistic worldview that takes human beings and all other natural beings as immanently residing in the divine substance. In other words, creation is one with the creator, the world one with God, and as such the two realities form a continuous whole or "All." ${ }^{62}$ Hegeler returns to this view in his article "What the Monistic Religion is to Me," which argues that the dualistic presuppositions implicit in our language are false. Terminological distinctions between "God" and "the universe," "soul" and "body," "force" and "matter" are merely "abstractions," whereas the truth is that these "complementary parts [...] together form the whole reality." 63 Hence, "All that exists, ourselves included, forms a great interacting whole, the most satisfactory name for which to me is the 'All.' Our relation to the All is like that of a snowcrystal to the ocean." ${ }^{64}$ Although Hegeler will say that the best way to describe the ultimate monistic reality is to use the term "All" rather than "God," he nonetheless continues to give it a religious connotation: "Religion, I was taught, is the union between ourselves and God through God."65

The religious aspect of Hegeler's monism also appears in his articulation of the ethics of meliorism. He describes the theory in his own words in "The Basis of Ethics," which probably was in part influenced by his reading of Carus's Monism and Meliorism around the time of its composition. ${ }^{66}$ Hegeler argues that the human race is undergoing an evolutionary development and that the greatest good takes the form of a kind of spiritual "immortality" in which our ideas are preserved by future generations. In this manner the human "soul" attains new heights from generation to generation. Moreover, Hegeler believes that science "gives us the conviction [...] that evolution is taking place throughout the universe - that God and the universe are one - are the continuous ALL of which man is a limited part and phenomenon." ${ }^{67}$ On this cosmological model, the progressive development of humankind is part of a greater world theodicy, and our finite contribution at any moment in history amounts to doing the will of God. Hegeler thus believes that "fundamentally the old religious dogma 'that is good or right which is the will of God' is true." 68 the title of his article, jointly composed with Carus, "Monism, Dualism, and Agnosticism," 
he names his arch-enemy, while Carus names dualism as Carus's. For Hegeler, the problem with agnosticism is that it denies the possibility of knowledge of a spiritual reality, and thus it is the ultimate antithesis to his faith in religion and consequently his religious monism. From the very beginnings of the Open Court, he drew a line in the sand between agnosticism and monism. The dichotomy would serve to frame his initial discontent of and final antagonism toward Underwood, with his liberalism and noncommitment ideology. Hegeler had accused Underwood of being agnostic throughout the entire time of their business partnership. This was despite Underwood defending his philosophical proclivities as partially monistic. When the two were disagreeing over the name for the journal, Underwood once wrote Hegeler explaining:

I believe that all phenomena, distinguished as mental and material have a common basis, in the ultimate nature of things. But when I say that I do not know what this ultimate nature is, I am in the company with Spencer and Huxley, with Haeckel and Buechner, even, as well as with Kant. ${ }^{69}$

This sort of skeptical monism was not good enough for Hegeler. Dispatching Underwood after a year for his designs in "the agnostic character of the paper," he tells the readers of The Open Court that agnosticism is "detrimental to the progress of knowledge and injurious to mankind in general. That I wanted to eradicate this idea, I had prominently pointed out to Mr. Underwood." 70

Hegeler's religious monism adds to our account of the philosophical origins of the Open Court, although it is not precisely commensurate with Carus's causal monism. In Monism and Meliorism and surrounding writings, God and spirituality do not prominently feature in Carus's solution of a world thoroughly and necessarily governed by the laws of cause and effect. "Causality is the law of cause and effect, and nothing else," Carus unambiguously states with no qualifications. ${ }^{71}$ While his conclusion is clear, it seems to fall short of his stated goal to equally incorporate the ideas of science and religion in a reconstruction of Kant's dualistic philosophy. Carus's own father Gustav Carus - a Lutheran pastor and church superintendent - was of the same opinion concerning his son's philosophy. He inveighed against Paul's monism for being irreligious, as well as for accepting certain unknowables, that is, for being agnostic! ${ }^{72}$ Statements made in Monism and Meliorism further contrast with Hegeler's views, such as its criticism of "dogmatism," the one-sided religious perspective departing from the impartial conciliation of religion with science on equal terms. Hegeler's zeal for a "new religion" of monism and reluctance to seriously entertain non-religious viewpoints arguably cross the line into dogmatism defined as such. In general, thus, Hegeler's interest in monism combines with a religious perspective that is in some ways at variance with Carus's sense of monism. It involves a deep existential commitment not found in Carus's formal philosophical presentations and diplomatic approaches to religion and science.

Nonetheless, Carus and Hegeler at the time of them becoming business partners recognized that they shared similar monistic worldviews - and indeed they did. The two men were committed to metaphysical, epistemological, and ethical principles unifying the multiplicity of the world: they sought to neither deny nor subordinate the rational or emotional aspects of human nature; believed that, at least in principle, religion and science were compatible; and held a faith in the moral evolution of the human race toward an ameliorative end. Their partnership in managing the Open Court was formed on these intellectual grounds, and as the business moved forward over the years, Carus would take the lead in promoting their shared philosophical views and defending them against their adversaries. 


\section{Epilogue: A Lesson in Meliorism}

One final thought will round out the study of the philosophical origins of the Open Court. It concerns the impact of Carus's career as staff-philosopher of the Open Court on his own philosophical development. What impact, if any, did his service to the company to promote its monistic mission have on his actual philosophical proclivities? As it turns out, the impact was significant.

Upon assuming his position as editor, Carus would immediately amend his earlier statements on monism to better reflect Hegeler's religious stance and antagonism toward agnosticism. This is evident by a mere examination of the titles of his new publications following his hiring: "Science and Religion" (1887), "Monism and Religion" (1888), "The Religious Character of Monism: In Reply to the Criticism of Dr. Gustav Carus" (1888), and The Idea of God (1888). These publications were all released as follow ups to his first article under Hegeler's tutelage, "Monism, Dualism, and Agnosticism," and before the end of his first year as editor-in-chief. Starting with these texts, Carus, loyal to Hegeler, took hold of a flag promoting a new "religion of science" while fighting off all forms of faithless agnosticism. ${ }^{73}$ This marked a new phase in Carus's philosophical development. Although the topic of religion was not entirely absent from his early career writings composed in Germany, it became a central topic of his research in the 1890 s and beyond..$^{74}$ As is well known, he became a major advocate for the validity of different world religions and he supported an international dialogue between representatives of Western and Eastern faiths, as conceived in his Religious Parliament Extension, successor of The World's Parliament of Religions. He also amended his philosophical theories, such as by logically coordinating the idea of God within his theory of causality. In The Idea of God and "The Religious Character of Monism," he defines God as the immanent "omnipresent order of the Cosmos" and "a law of Nature." ${ }^{5}$ Henderson explains that Carus "redefined 'God' as the universal system of necessary laws discovered by science." ${ }^{" 76}$

Yet, Carus simultaneously seemed aware that he was sacrificing some of his own personal values while advocating for what he called Hegeler's more "positive" agenda. In a candid letter to Peirce in 1892, he explains that his duties to Hegeler conflict with his own standards as a philosopher and an editor:

Mr. Hegeler is not narrower than I am, but I should say that he is more positive. I would restrain editorial interference to matters of principle only, and leave the working out of our aim to the contributors, admitting, however, the editor as one of the contributors. As such I would often abide my time longer than I do. So, for instance, my proposition was to name the new quarterly "THOUGHT" and not "THE MONIST"; but in Mr. Hegeler's opinion, the name "THOUGHT" was unmeaning. He regarded it as an attempt at being non-committal. He wants to have the solution which he arrived at expressed unequivocally. The name of the journal is to him the flag; while to me it would be an invitation to the class of people who are welcome to contribute. Mr. Hegeler had the same objection to the name, "THE OPEN COURT." I shall be pleased to have your article for the Fall number of the MONIST. ${ }^{77}$

Peirce responded that Thought "would have been a superb" title. ${ }^{78}$ That name for Peirce reflected the essence of an ideal community of inquirers who collectively pursue the truth in and for itself, without any ulterior motives. Peirce and Carus both fancied themselves as participating in such a community. Testament to this is Carus's welcoming disposition to receive a new article by Peirce's hand for the fall issue of the The Monist.

European Journal of Pragmatism and American Philosophy, IX-2 | 2017 
That gesture was made in May, the time precisely after the publication of "The Doctrine of Necessity Examined" and in the midst of the two philosophers quarreling over the truth of determinism. Thus, despite vehemently disagreeing with Peirce on the topic, Carus would not silence Peirce's opinion and even welcomed its expression as one liveoption amongst the community of inquirers.

Carus's candid admissions to Peirce about his relationship with Hegeler and his compromises as an editor reveal his true feelings about his assignment to promote an Open Court philosophy. There is serious irony in Carus reiterating the same liberal positions as his predecessor Underwood with regard to the name of the Open Court journal and to its editorial practices. As we know, such a stance did not end well for Underwood. Carus, however, managed to remain Hegeler's right-hand man for the long run. This was in part because, of course, his writings helped inspire and articulate the monistic platform of the Open Court from its inception. Yet, it also seems it was due to him making a necessary and personal act of conciliation in sacrificing some of his intellectual autonomy for a vision of the greater good. By this act he was in accordance with the "must" and "ought" of the melioristic improvement of the human race demanded by his and Hegeler's ethics - an ethics of monism, then, that more than theoretically grounded the founding of the Open Court.

\section{BIBLIOGRAPHY}

BECK Lewis White, (1996), “Neo-Kantianism," The Encyclopedia of Philosophy, New York, Simon \& Schuster Macmillan, 5-6, 468-73.

CARUS Gustav, (1888), "Christianity and Monism: A Criticism of the Work of 'The Open Court'," The Open Court, 2, 44, 1381-4.

CARUS Paul, (1881), Metaphysik in Wissenshaft, Ethik und Religion: Eine Philosophische Untersuchung, Dresden, R. von Grumbkow, Hof-Verlag.

CARUS Paul, (1883), Ursache, Grund und Zweck: Eine Philosophische Untersuchung zur Klärung der Begriffe, Dresden, R. von Grumbkow, Hof-Verlag.

CARUS Paul, (1885), Monism and Meliorism: A Philosophical Essay on Causality and Ethics, New York, F. W. Christern.

CARus Paul, (1887), “Monism, Dualism, and Agnosticism,” The Open Court, 1, 8, 209-12.

CARUS Paul, (1888), “The Religious Character of Monism: In Reply to the Criticism of Dr. Gustav Carus," The Open Court, 2, 44, 1381-4.

CARUS Paul, (1889), Fundamental Problems: The Method of Philosophy as a Systematic Arrangement of Knowledge, Chicago, The Open Court Publishing Company.

CARUs Paul, (1890), “The Vocation,” The Open Court, 3, 46, 2027-8.

CARUS Paul, (1891-2), Monism its Scope and Import: A Review of the Work of the Monist, Chicago, The Open Court Publishing Company. 
CARUS Paul, (1892a), “Monism not Mechanism: Comments upon Prof. Ernst Haeckel's Position,"

The Monist, 2, 3, 438-42.

CARUS Paul, (1892b), "Charles S. Peirce's Onslaught on the Doctrine of Necessity," The Monist, 2, 4, $560-82$.

CARUS Paul, (1892c), “Professor Haeckel's Monism,” The Monist, 2, 4, 598-600.

CARUS Paul, (1896 [1888]), The Idea of God, Chicago, The Open Court Publishing Company.

CARus Paul, (1913), “The Monism of 'The Monist': Compared with Professor Haeckel's Monism,”

The Monist, 23, 3, 435-9.

THE CHARLES S. PEIRCE PAPERS, Houghton Library, Cambridge.

FLYNN Tom, (2007), “Underwood, Benjamin Franklin (1839-1914)," The New Encyclopedia of Unbelief, Amherst, Prometheus, 775.

GOEBel Julius, (1919), "Paul Carus," The Open Court, 33, 9, 513-21.

GUARDIANO Nicholas L., (2011), “The Intelligibility of Peirce's Metaphysics of Objective Idealism,” Cognitio: Revista de Filosofia, 12, 2, 187-204.

GUARdiano Nicholas L., (2017a), Aesthetic Transcendentalism in Emerson, Peirce, and NineteenthCentury Landscape Painting, Lanham, Lexington Books.

GUARDIANO Nicholas L., HACKBART-DEAN Pamela \& Aaron C. LISEC, (2017b), An Independence of Ideas and Thought: The Life of Mary Hegeler Carus, Carbondale, Saluki Press.

HAY William H., (1956), "Paul Carus: A Case-Study of Philosophy on the Frontier," Journal of the History of Ideas, 17, 4, 498-510.

HEGELER Edward C., (1887a), “The Basis of Ethics,” The Open Court, 1, 1, 20-1.

HEGELER Edward C., (1887b), "To the Readers of the Open Court," The Open Court, 1, 22, 621-40.

HEGELER Edward C., (1888), "What the Monistic Religion is to Me," The Open Court, 1, 25, 725-6.

HENDERSON Harold, (1993), Catalyst for Controversy: Paul Carus of Open Court, Carbondale, Southern Illinois University Press.

HENDERSON Harold \& André W. CARUS, (2005), "Carus, Paul (1852-1919)," The Dictionary of Modern American Philosophers, Bristol, Thoemmes Continuum, 1, 445-9.

HoLton Gerard, (1993), "From the Vienna Circle to Harvard Square: The Americanization of a European World Conception," in Stadler Friedrich (ed.), Scientific Philosophy: Origins and Developments, Dordrecht, Kluwer Academic Publishers.

HOLZHEY Helmut \& Vilem MUDROCH, (2005), Historical Dictionary of Kant and Kantianism, Lanham, The Scarecrow Press.

JENSEN Anthony K., (2017), “Neo-Kantianism," Internet Encyclopedia of Philosophy, http://www.iep.utm.edu/neo-kant/, September 8, 2017.

KÖHNKE Klaus Christian, (1991), The Rise of Neo-Kantianism: German Academic Philosophy between Idealism and Positivism, Hollingdale R. J. trans., Cambridge, Cambridge University Press.

LOHNE Raymond, (2012), “Mary Hegeler Carus (1861-1936),” Immigrant Entrepreneurship: GermanAmerican Business Biographies, 4, [http://immigrantentrepreneurship.org/entry.php?rec=109]. 
OLLIG Hans-Ludwig, (1998), “Neo-Kantianism,” Michael J. \& Walker N. trans., Routledge

Encyclopedia of Philosophy, 6, London, Routledge, 776-92.

THE OPEN COURT PUBLISHING COMPANY RECORDS, Morris Library, Carbondale.

RUETENIK Tadd, (2008), “Meliorism,” American Philosophy: An Encyclopedia, New York, Routledge, 498-500.

RYAN W. F., (1985), “Underwood, Benjamin Franklin (1839-1914),” The Encyclopedia of Unbelief, Buffalo, Prometheus, 2, 677-9.

SHIN Kee Soo, (1973), “Paul Carus's ‘Positive Monism' and Critique of Other Types of Monism (Mach, Haeckel, Peirce)," Ph.D. diss., Temple University.

URBAS Joseph, (2016), Emerson's Metaphysics: A Song of Laws and Causes, Lanham, Lexington University Press.

WILLEY Thomas E., (1978), Back to Kant: The Revival of Kantianism in German Social and Historical Thought, 1860-1914, Detroit, Wayne State University Press.

THE WORKS OF WILLIAM JAMES, 19 vols., ed. Frederick H. Burkhardt, Harvard University Press, Cambridge (1975-88).

WRITINGS OF C. S. PEIRCE: A CHRONOLOGICAL EDITION, 7 vols. published, ed. by M. Fisch et al., Indiana University Press, Bloomington, 1982-.

\section{NOTES}

1. Hegeler (1887b: 624), Edward C. Hegeler to Benjamin F. Underwood, 19 September 1886.

2. Hegeler (1887b: 627-8), Hegeler to Underwood, 7 December 1886.

3. Hegeler (1887b: 627), Hegeler to Underwood, 3 December 1886.

4. Hegeler (1887b: 627), Hegeler to Underwood, 3 December 1886.

5. For biographical information on the Underwoods, see Ryan 1985 and Flynn 2007.

6. Hegeler (1887b: 629), Underwood to Hegeler, 7 December 1886.

7. Hegeler (1887a: 15).

8. Ibid.

9. In section 3 below, I return to Hegeler's disdain for agnosticism in his relationship with the Underwoods.

10. Hegeler (1887b: 639), Hegeler to Paul Carus, 21 January 1887.

11. For biographical accounts of Carus's early life, see Shin (1973: 18-32), Henderson (1993: 7-11), and Henderson \& Carus 2005.

12. Mary Hegeler Carus was an exceptional person in her own right and broke through many gender barriers of her time. She oversaw as a young girl some of the operations of the zinc smelters at her father's business, the Matthiessen \& Hegeler Zinc Company; was the first woman to graduate with a bachelor's degree in engineering from the University of Michigan; was one of the first two women to be admitted to and to complete a degree from - despite not being awarded it because of her gender - the Bergakadamie Freiberg, a prestigious mining school in Germany; became the president of the M\&H Zinc Company upon her father's death; and became the editor-in-chief of the Open Court upon her husband's death. For a biography of her life, see Lohne 2012 and Guardiano et al. 2017b.

13. Hegeler (1887b: 621). This first appearance of the new standing notice in the issue of 22 December 1887 was the final issue of the year.

14. Henderson (1993: 14). 
15. See Henderson \& Carus (2005: 447). For a succinct account of Carus's monism in relation to his later writings and philosophy of form, see Hay 1956.

16. See esp. Carus (1881: sec. 17).

17. Carus (1883: 43); my translation.

18. See Hegeler (1887b: 636), and Henderson (1993: 37).

19. Carus (1885: 5$)$.

20. Carus (1885: 7).

21. Ibid.

22. On Carus's education and teaching career, see Henderson (1993: 4-5) and Goebel (1919: 513).

23. For more on the rise of neo-Kantianism, its schools, and main figures, see Willey 1978, Köhnke 1991, Beck 1996, Ollig 1998, Holzhey \& Mudroch 2005, and Jensen 2017.

24. Köhnke (1991: 137).

25. See Köhnke (1991: 124-35). Carus will also reject materialism in his early writings; see Carus (1881: sec. 17) and Carus (1885: 80).

26. Carus (1885: 12).

27. Ibid. For more on Carus's understanding of the terms materialism, spiritualism, idealism, realism, and others, see the appendix of definitions in Carus (1885: 78-83).

28. Carus (1885: 12-3).

29. Carus (1885: 15).

30. Carus (1885: 27-8).

31. W8: 106.

32. Ibid.

33. W8: 43. For more on Peirce's critique of neutralism, including its possible further identification with the philosophies of Ernst Mach and Baruch Spinoza, see Guardiano 2011. Mach had an extensive correspondence with Carus and published numerous articles and books with the Open Court. For a brief note on their relationship, see Holton (1993: 48-50). Holton brings to light Carus's generosity as an editor by promoting Mach's writings to America and the English-speaking world. However, in his excitement to show that Carus "clearly revered" Mach, he hastily associates Carus's philosophy with Mach's positivistic and anti-metaphysical stance, and even claims that Carus held an agnostic monistic worldview. On the contrary, Carus's monism is a form of neutralism incorporating both scientific and religious sentiments. Furthermore, as we have seen, he promoted the Open Court's primary agenda of conciliating religion with science, and in this regard was indispensable ally to Hegeler, who took agnosticism as scourge of his publishing company.

34. Carus (1887: 209).

35. Carus (1885: 29).

36. Carus (1885: 62).

37. See Shin (1973: 103), which explains the theoretical comprehensiveness of monism under these three aspects.

38. Carus (1881: 24); my translation.

39. Carus (1881: 25); and see Carus (1881: secs. 2 and 17). Contrary to Carus, the neo-Kantians Fisher and Leibmann reject the idea of the thing-in-itself as a nonsensical idea. Carus's view thus appears closer to those of Hermann von Helmholtz and Lange who take the objects of experience to exist as products of the metaphysical thing-in-itself interacting with the sense and cognitive capacities of the human organism. On the neo-Kantian history here, see Beck (1996: 469) and Köhnke (1991: 163-4).

40. Shin (1973: chap. 5) makes a start of a complete study.

41. Carus (1892b: 563$)$.

42. Carus (1892b: 564).

43. Carus (1892b: 578). 
44. See Carus (1892b: 569-72).

45. See Paul Carus to Charles S. Peirce, 10 September 1913, The Charles S. Peirce Papers (L77: 251-2); and Paul Carus to Francis C. Russell, 5 January 1918, letterpress of original, The Open Court Publishing Company Records (box 91, folder 7).

46. See Henderson (1993: 146-7).

47. W8: 105.

48. See the following articles published in The Monist for Carus's debate with Haeckel on the theory of monism: Carus 1892a, Carus 1892c, and Carus 1913. Also, Shin treats at length the subject of Carus's monism vis-à-vis Haeckel's monism in Shin (1973: chap. 3).

49. Carus (1885: 53)

50. Hegeler (1887a: 20-1). This article, originally delivered as a lecture on 14 January 1887, was printed with revisions in the first issue of The Open Court on 17 February 1887. Although its composition occurred prior to Carus arriving in La Salle, it is highly probable that Hegeler's ideas were directly influenced by Carus's ethical discussions in Monism and Meliorism, since the week after the lecture on 21 January Hegeler first wrote to Carus praising his book.

51. Carus (1885: 69).

52. Carus (1885: 71)

53. Carus (1887: 211).

54. Ibid.

55. See WWJ1: 12-4, 60-1, and 136-8. For a general discussion of the topic of meliorism in the greater pragmatist tradition, also see Ruetenik 2008.

56. W8: 110 .

57. For a full discussion of these creative aspects of Peirce's evolutionary cosmology, see Guardiano (2017a: chap. 3).

58. See W8: 192, footnote 2.

59. Ralph Waldo Emerson's cosmic meliorism shares much in common with Peirce's agapism. It is a metaphysics of cosmic proportions involving the metamorphic ascension of things towards higher and higher forms. For a trenchant account of it, see Urbas (2016: 163-4); also, see Guardiano (2017a: chap. 1, sec. 3).

60. Hegeler (1887b: 624), Hegeler to Underwood, 19 September 1886; my emphasis.

61. Hegeler (1887b: 627), Hegeler to Underwood, 3 December 1886.

62. Carus at a later date while articulating the theological underpinnings of his and Hegeler's joint philosophical perspective will reject pantheism although not panentheism. Pantheism takes God to be one with creation, in the sense that God's entire being is exhausted by the reality of nature, whereas panentheism takes God's being to ultimately extend beyond the reality of nature. See e.g. Carus (1885: 63) and Carus (1896: 26-33).

63. Hegeler (1888: 725). Carus likewise takes the opposing elements of dualism to be merely conceptual "abstractions" from an original unitary reality; see e.g. Carus (1891-2: 7) and Carus (1889: 18).

64. Hegeler (1888: 725).

65. Ibid.

66. See n. 50 above.

67. Hegeler (1887a: 21).

68. Hegeler (1888: 725).

69. Hegeler (1887b: 629), Underwood to Hegeler, 7 December 1886.

70. Hegeler (1887b: 636).

71. Carus (1885: 45). One exception in this text occurs during Carus's argument against the idea of God as first cause of the universe. There he seems amenable to associating God with the principle of causality itself. He states: "We reject and condemn, therefore, the idea of a first cause in the sense of Creator, as a contradiction in itself. And those who call God the first cause have 
either a vague idea of what they mean, or they intend to say that God is the final principle of the world, the most general law, governing the whole universe, the fundamental basis, and, so to speak, the ground on which everything rests, from which all existences spring and originate, and the ultimate reason to which we trace the existence of the cosmos. Such a principle, or whatever other name you may be pleased to give it [read: e.g. "God"], is not a passing cause, which happens once and exists no longer, but a living presence, which pervades the whole world, and is the operating force in all causes and the causation in causality" (ibid.: 46). For a similar comment appearing in a text after Monism and Meliorism, see Carus (1889: 17) where Carus equates the "cosmical order of the Universe" with God.

72. Gustav's views are expressed in his article Carus G. 1888.

73. For this transition in Carus's career, see Henderson (1993: 45-7) and Carus (1890: 2027-8).

74. Carus discusses religion in his early career writings Metaphysik in Wissenschaft, Ethik und Religion (1881), Quid est Veritas? Eine Religiöse Entwicklung in Gedichten (1881), and Lieder eines Buddhisten (1882).

75. Carus (1896: 27), and Carus (1888: 1384).

76. Henderson (1993: 47).

77. Paul Carus to Charles S. Peirce, 31 May 1892, The Charles S. Peirce Papers (L77: 16). A letterpress made from the original letter is in The Open Court Publishing Company Records (box 91, folder 11).

78. Charles S. Peirce to Paul Carus, 3 June 1892, The Open Court Publishing Company Records (box 91, folder 11).

\section{ABSTRACTS}

In 1887 the Open Court Publishing Company had its founding in a philosophy of monism. The company's proprietor Edward C. Hegeler began the enterprise in an effort to promote his personal philosophic, religious, and moral ideas. He believed that these ideas could be conciliated with the growing scientific trends of the late nineteenth century, and that monism was the intellectual framework for doing so. Paul Carus, the editor of the journals The Open Court and The Monist, joined Hegeler as an intellectual ally in this regard. For thirty years he openly defended the doctrines of monism in countless articles and books, successfully grounding the Open Court on this philosophy. This paper uncovers the historical development of the philosophical origin of the Open Court as it began with Hegeler's personal religious motives, his ideological tension with the original editor Benjamin Underwood, and his embrace of the monistic writings of Paul Carus. It also examines Hegeler's and Carus's publications and personal letters from the 1880s and 1890s in order to determine the fundamental doctrines of their unique sense of monism. In Carus's writings in particular is proposed a monism of causality that is compatible with a deterministic worldview and a unitary conception of the sciences. Also, both Carus and Hegeler propose a monistic ethics of meliorism that conceives the diverse periods of human history to be evolving toward the one final end of the moral improvement of humankind. While these are the positive doctrines that they accept, they further reject the antitheses of philosophical dualism and irreligious attitude of agnosticism of all varieties. 


\section{AUTHOR}

\section{NICHOLAS L. GUARDIANO}

Southern Illinois University Carbondale

nguardia[at]siu.edu 